\title{
PENGUATAN RUMAH TANGGA NELAYAN KECIL DALAM MENGAKSES MODAL UNTUK PENGEMBANGAN USAHA PERIKANAN TANGKAP DI DESA TANJUNG LUAR KABUPATEN LOMBOK TIMUR
}

\author{
Syarif Husni ${ }^{*}$, Abubakar, dan M. Yusuf \\ Program Studi Agribisnis Fakultas Pertanian Universitas Mataram \\ ${ }^{*}$ Korespondensi: syarifhusni1964@gmail.com
}

Diterima 5 November 2018 / Disetujui 6 Desember 2018

\begin{abstract}
ABSTRAK
Kehidupan nelayan kecil kerap dihadapkan berbagai persoalan rendahnya produktivitas, keterbatasan modal, keterbatasan teknologi, minimnya ketersediaan bahan bakar dan lainlain. Kesulitan pada akses permodalan merupakan salah satu faktor yang membuat nelayan sulit berkembang baik kesejateraanya maupun untuk peningkatan produktivitasnya. Tujuan kegiatan pengabdian pada masyarakat adalah melakukan sosialisasi tentang peranan modal untuk kegiatan usaha produktif dan sosialisasi akses modal (kredit usaha mikro) bagi peningkatan skala usaha pada rumah tangga nelayan kecil di Desa Tanjung Luar. Metode kegiatan pengabdian menggunakan metode sosialisasi, dan metode Focuss Group Discussion (FGD)/Diskusi Kelompok Terarah, yaitu metode dalam pengumpulan data dan informasi mengenai masalah tertentu yang sangat spesifik melalui diskusi kelompok. Kesimpulan dari kegiatan ini adalah meningkatnya pemahaman dan kesadaran nelayan di Desa Tanjung Luar akan pentingnya modal bagi kegiatan usaha serta tingginya minat rumah tangga nelayan untuk mengakses kredit mikro yang disediakan oleh lembaga keuangan perbankan
\end{abstract}

Kata kunci: akses modal, kredit mikro

\section{PENDAHULUAN}

Indonesia memiliki laut dengan luas 5,8 juta $\mathrm{km} 2,17.508$ pulau dan garis pantai dengan panjang $81.000 \mathrm{~km}$. Propinsi NTB memiliki potensi sumberdaya pesisir dan laut yang cukup besar yang terbentang sepanjang Pulau Lombok dan Sumbawa. Luas perairan laut sekitar $29.159,04 \mathrm{~km} 2$, panjang pantai $2.333 \mathrm{~km}$ dan perairan karang sekitar $3.601 \mathrm{~km}$. Potensi lestari perikanan di NTB 129.863 ton/tahun yang terdiri atas potensi lestari ikan pelagis $55.917,4$ ton/tahun dan potensi ikan demersal sebesar 73.945,6 ton /tahun. Kabupaten Lombok Timur yang memiliki wilayah pesisir yang luas di Pulau Lombok dihuni oleh sebagian besar nelayan kecil.

Dengan karunia sumberdaya pesisir dan lautan tersebut, seyogyanya masyarakat mempunyai tingkat kesejahteraan yang mapan, terutama yang bermukim di wilayah pesisir dan kepulauan. Namun sayangnya, justru kelompok nelayan mengalami kesulitan untuk memenuhi kebutuhan dasarnya 
seperti sandang dan pangan. Masyarakat nelayan dikategorikan sebagai masyarakat miskin dengan indikasi bahwa tingkat perekonomiannya masih lemah karena tingkat pendapatan yang rendah, kualitas hidupnya rendah, kesejahteraan sosial rendah dan hidup dalam kesulitan (Baso, A., 2013). Hal ini terjadi sejak Orde Baru sampai masa reformasi sekarang ini yang dibuktikan dengan beberapa hasil penelitian antara lain Mubyarto, et al (1984) serta Mubyarto dan Sutrisno (1988) dan Kusnadi (2013) serta Wiber, et al (2009) disebabkan oleh beberapa faktor yaitu suasana alam yang keras menyebabkan timbulnya ketidakpastian bagi nelayan dalam menjalankan aktivitas sosial ekonomi yang terus menerus dalam menjaga konsistensi produksi hasil tangkapan, kualitas sumber daya manusia nelayan yang rendah, keterbatasan modal usaha menyulitkan nelayan untuk meningkatkan kegiatan ekonominya, pemasaran hasil perikanan yang lebih menguntungkan perantara, dan program pemerintah yang belum memihak nelayan. Kemiskinan dicirikan oleh rendahnya pendapatan dan cenderung tidak menentu setiap saat. Rendahnya pendapatan ini berujung pada sulitnya mengakses pendidikan dan kesehatan yang layak. Rendahnya pendidikan menyebabkan lemahnya daya saing rumah tangga miskin dalam memperebutkan peluang pekerjaan yang lebih layak secara ekonomi. Selain itu, tingkat pendapatan yang rendah menyebabkan kemampuan untuk melakukan akumulasi modal menjadi sangat terbatas. Oleh karena itu, rumah tangga miskin tidak dapat mengakses teknologi yang mampu meningkatkan pendapatan rumah tangga mereka. Keadaan ini sangat sesuai dengan teori lingkaran kemiskinan.. Akses pendapatan yang diperoleh dihabiskan sepenuhnya untuk memenuhi kebutuhan hidup rumah tangga. Peluang untuk melakukan investasi tidak dapat dilakukan karena rendahnya tingkat pendapatan. Sebenarnya rumah tangga miskin memperoleh kesempatan untuk mengakses modal finansial melalui lembaga perkreditan. Namun demikian, akses ini tidak digunakan dengan baik karenas sulitnya persyaratan yang harus dipenuhi (Widodo, 2011).

Kehidupan nelayan tradisional dan nelayan kecil kerap dihadapkan berbagai persoalan rendahnya produktivitas, keterbatasan modal, keterbatasan teknologi, minimnya ketersediaan bahan bakar dan lain-lain. Kesulitan pada akses permodalan merupakan salah satu faktor yang membuat nelayan sulit berkembang baik kesejateraanya maupun untuk peningkatan produktivitasnya

Desa Tanjung Luar Kabupaten Lombok Timur sebagai salah satu pusat perikanan tangkap di Pulau Lombok. Sebagaian besar masyarakat di desa ini menggantungkan hidupnya pada perikanan tangkap yaitu sebagai nelayan dengan jumlah nelayan kecil terbanyak (80\%) dengan tingkat sosial ekonomi yang rendah.

Persoalan modal menjadi kendala dalam utama pengembangan skala usaha baik pada perikanan tangkap maupun pada usaha bakulan yang dilakukan oleh wanita nelayan. Kondisi rumahtangga nelayan selama ini sebagai faktor kendala dalam akses terhadap sumber modal baik pada lembaga keuangan formal dan informal. Di Desa Tanjung Luar kebanyakan wanita nelayan berprofesi sebagai pedagang ikan dengan tingkat keuntungan $\mathrm{Rp}$ 25.000-50.000 per hari begitu pula pendapatan sebagai nelayan 
yang tidak menentu. Pada umumnya rumah tangga nelayan kecil cenderung mengakses modal dari lembaga keuangan informal seperti bakulan, pedagang besar, pengijon dan rentenir dengan tingkat bunga yang tinggi, dan jarang bahkan sama sekali berhungan dengan lembaga keuangan formal.

Tujuan kegiatan pengabdian pada masyarakat adalah melakukan sosialisasi tentang peranan modal untuk kegiatan usaha produktif dan sosialisasi akses modal (kredit usaha mikro) yang bagi peningkatan skala usaha pada rumah tangga nelayan kecil di Desa Tanjung Luar.

\section{METODE KEGIATAN}

Metode kegiatan yang digunakan dalam pengabdian pada masyarakat adalah melalui Metode Sosialisasi, yaitu metode melalui proses sosial yang terjadi pada seseorang untuk mempelajari dan menyesuaikan diri terhadap norma, nilai, perilaku, adat istiadat, dan semua persyaratan lainnya yang diperlukan agar dapat berperan dan berfungsi dalam kelompoknya. Sosialisasi juga dilakukan dengan memberikan pemahaman dan wawasan masyarakat melalui media gambar dan lefleat dan spanduk.

Selain itu metode yang digunakan juga Metode Focuss Group Discussion (FGD)/Diskusi Kelompok Terarah, yaitu metode dalam pengumpulan data dan informasi mengenai masalah tertentu yang sangat spesifik melalui diskusi kelompok.

\section{HASIL DAN PEMBAHASAN}

\section{Sosialisasi Kegiatan}

Kegiatan sosialisasi akses modal
bagi rumah tangga nelayan keecil

dilaksanakan di rumah nelayan Desa Tanjung Luar pada hari Sabtu tanggal 27 Oktober 2018, dihadiri oleh stakeholders yang ada di desa tersebut, terdiri dari nelayan, tokoh masyarakat, aparat desa, tokoh agama dan pemuda nelayan. Jumlah peserta yang hadir 40 orang. Acara sosialisasi dibuka oleh dipandu oleh salah satu Tokok mayarakat, yaitu M. Abbas Hasan. Dalam sambutannya masyarakat Desa Tanjung Luar berterima kasih atas kegiatan penyuluhan dan sosialisasi yang dilakukan oleh Tim Penyuluhan dari Unram, semoga kegiatan ini dapat bermanfaat bagi peningkatkan kesejahteraan masyarakat

Modal memegang peranan penting bagi rumah tngga nelayan dalam kegiatan baik dalam bentuk on-fishing, off fishing maupun non fishing. Keberadaan modal di kalangan nelayan menjadi salah satu faktor penghambat dalam peningkatan skala usaha

Permodalam kerap kali menjadi kendala bagi masyarakat nelayan. Sulitnya akses hingga ketidaktahua masyarakat tentang lembaga pendanaan menjadi beberapa faktor nelayan enggan mengurus kredit.Ketergantungan nelayan terhadap permodalan mandiri, penyisihan keuntungan usaha, meminjam dari anggota keluarga ataupun dari sumber keuangan informal lainnya masih sangat tinggi terjadi di Indonesia.

Kelemahan selama ini yang masih ada pada pelaku UMKM yang membuat sektor ini sulit berkembang adalah akses permodalan dan akses ke sumber pembiayaan yang sangat terbatas. Selain itu, keterbatasan sumber daya manusia (SDM), kesulitan bahan baku, hingga keterbatasan inovasi dan teknologi. Padahal UMKM menjadi salah satu sektor yang mampu menunjang perekonomian 
nasional. Bahkan sektor ini pun bisa memberikan lapangan kerja yang kemudian menurunkan angka kemiskinan.

Peran UMKM sebagai pelaku ekonomi yang jumlahnya kurang lebih sekitar 57,9 juta atau 99,9 persen dari total jumlah pelaku usaha nasional, dalam lima tahun terakhir memberikan kontribusi terhadap kesempatan kerja mencapai 97 persen atau 107,7 juta orang. Kontribusinya terdahap pembentukan produk domestik bruto (PDB).

Satu hal yang harus digenjot kembali adalah kontrobusi produk UMKM dalam pangsa ekspor. Saat ini kontribusi ekspor masih berada di angka 15,8 persen. Jauh tertinggal dibanding negara-negara sekawan di Asia Tenggara lainnya. Misal, Thailand mencapai kontribusi ekspor sebesar 29,5 persen, dan Filipina capai 20 persen.Sebagian besar pelaku UMKM kita tidak memiliki informasi dan akses ke pasar global. Kondisi ini merupakan tantangan sekaligus pekerjaan rumah yang harus ditangani secara bersama.

Sumber modal bagi nelayan kecil yang bisa diakses dengan bunga murah adalah melalui kredit usaha mikro:

a. Kredit Usaha Mikro : Kredit Modal Kerja dan atau Kredit Investasi dengan batas hinggaRp 500 juta diberikan kepada usaha mikro, usaha kecil dan koperasi dengan bisnis produktif yang akan mendapat jaminan dari perusahaan Penjamin

b. Keuntungan

1) KUR Mikro BANK BRI : Kredit Modal Kerja dan atau Investasi dengan plafond s.d Rp 25 juta per debitur

2) KUR Ritel BANK BRI: KUR Ritel BANK BRI adalah Kredit Modal Kerja dan atau Investasi kepada debitur yang memiliki usaha produktif dan layak dengan plafond > Rp 25 juta s.d Rp 500 juta per debitur

3) KUR TKI BANK BRI :KUR TKI BANK BRI diberikan untuk membiayai keberangkatan calon TKI ke negara penempatan dengan plafond s.d Rp 25 juta

\section{c. Persyaratan Calon Debitur}

1) KUR Mikro BANK BRI

- Individu (perorangan) yang melakukan usaha produktif dan layak

- Telah melakukan usaha secara aktif minimal 6 bulan

- Tidak sedang menerima kredit dari perbankan kecuali kredit konsumtif seperti KPR, KKB, dan, Kartu Kredit

- Persyaratan administrasi : Identitas berupa KTP, Kartu Keluarga (KK), dan surat ijin usaha

2) KUR Ritel BANK BRI

Mempunyai usaha produktif dan layak

- Tidak sedang menerima kredit dari perbankan kecuali kredit konsumtif seperti KPR, KKB, dan, Kartu Kredit

- Telah melakukan usaha secara aktif minimal 6 bulan

- Memiliki Surat Ijin Usaha Mikro dan Kecil (IUMK) atau surat ijin usaha lainnya yang dapat dipersamakan

3) KUR TKI BANK BRI

- Individu (perorangan) calon TKI yang akan berangkat bekerja ke negara penempatan.

- Persyaratan administrasi:

a. Identitas berupa KTP dan Kartu Keluarga b. Perjanjian kerja dengan pengguna jasa 
c. Perjanjian penempatan

d. Passpor

e. Visa

f. Persyaratan lainnya sesuai ketentuan

\section{d. Persyaratan Kredit}

1) KUR Mikro BANK BRI

$>$ Besar kredit maksimal sebesar Rp 25 juta per debitur

Jenis kredit :

a. Kredit Modal Kerja (KMK) jangka waktu maksimal 3 (tiga) tahun

b. Kredit Investasi (KI) jangka waktu maksimal 5 (lima) tahun

- Suku bunga $7 \%$ efektif per tahun atau setara $0.41 \%$ flat per bulan

> Tidak dipungut biaya provisi dan administrasi

2) KUR Ritel BANK BRI

$>$ Besar kredit > Rp 25 juta - Rp 500 juta

Jenis kredit :

a. Kredit Modal Kerja (KMK) jangka waktu maksimal 4 (empat) tahun

b. Kredit Investasi (KI) jangka waktu maksimal 5 (lima) tahun

> Suku bunga $7 \%$ efektif per tahun

$>$ Tidak dipungut biaya provisi dan administrasi

Agunan sesuai ketentuan bank

3) KUR TKI BANK BRI

D Besar kredit maksimal Rp 25 juta atau sesuai Cost Structure yang ditetapkan pemerintah

Suku bunga $7 \%$ efektif per tahun atau setara $0.41 \%$ flat per bulan

$>$ Tidak dipungut biaya provisi dan administrasi

Jangka waktu maksimal 3 (tiga) tahun atau sesuai kontrak kerja

$>$ Tujuan negara penempatan: Singapura, Hongkong, Taiwan,
Brunei, Jepang, Korea Selatan, dan Malaysia

\section{Sosialisasi Melalui Brosur}

Sosialisasi yang lain dalam akses modal ini adalah melalui penyebar luasan informasi kepada seluruh masyarakat melalui mealui brosur (Gambar 1). Sosialisasi seperti ini diharapkan lebih efektif karena pesannya lebih mengena dan menganut unsur propaganda.

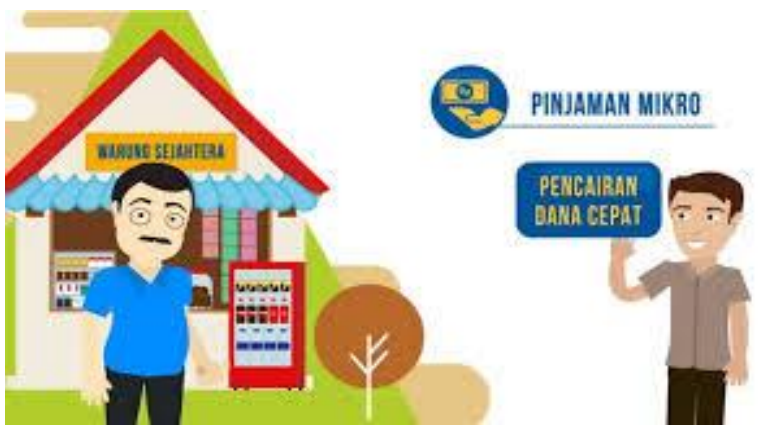

Gambar 1 Sosialisasi melalui brosur

\section{KESIMPULAN DAN SARAN \\ Kesimpulan}

Kesimpulan dari pelaksanaan kegiatan ini adalah meningkatnya pemahaman dan kesadaran nelayan di Desa Tanjung Luar akan pentingnya modal bagi kegiatan usaha. Tingginya minat rumah tangga nelayan untuk mengakses kredit mikro yang disediakan oleh lembaga keuangan perbankan.

\section{Saran}

Akses kedit mikro di kalangan nelayan perlu diintensifkan sebagai sumber modal. Pihak perbankan perlu terlibat secara aktif dalam sosialisasi tentang kredit usaha mikro di kalangan rumah tangga nelayan. 


\section{DAFTAR PUSTAKA}

Anwar, K., Ismail dan Boesono, 2014. Analisis Tingkat Kesejahteraan Nelayan Payang di Desa Munjungagung Kecamatan Kramat Kabupaten Tegal. Journal of Fisheries Utilization Management and Technology. Volume 3 No 3 Tahun 2014. http://www.ejournalsl.undip.ac.id/index.php/jfrumt.

Bailey, Conner, 1987. Government Protection of Traditional Resources Use Rights. The Case of Indonesia Fisheries. Dalam David C. Korten (ed). Community Management Asian Experience and Prospectives. West Hartford, Kumarian.

Baso, 2013. Revitalisasi Pemberdayaan Masyarakat Pesisir Bagi Kesejahteraan Nelayan. Dalam Buku Membangun Sumber Daya Kelautan Indonesia: Gagasan dan Pemikiran Guru Besar Universitas Hasanuddin. IPB Press dan Hasanuddin University Press,

Kusnadi, 2002. Konflik Sosial Nelayan: Kemiskinan dan Perebutan Sumberdaya Perikanan. LKIS, Yogyakarta.

Mubyarto, Lukman Soetrisno dan Michael Dove, 1984. Nelayan dan Kemiskinan. Sudi Ekonomi Antropologi di Dua Desa Pantai. Rajawali, Jakarta.

Nasution ZS, Hartono,., 2007. Sosial Budaya masyarakat Nelayan. Konsep dan Indikator Pemberdayaan. Balai Besar Riset Sosial Ekonomi Kelautan dan Perikanan Jakarta.
Satria, 2003. Menuju Gerakan Kelautan. Jurnal Agrimedia. Volume 8 Nomor 2, April 2003

Widodo, S., 2011. Strategi Nafkah Berkelanjutan Bagi Rumah Tangga Miskin di Daerah Persisir. Jurnal Peneltian Makara, Sosial Humaniora, Volume 15 No 1, Juli 2011. Fakultas Pertanian Universitas Trunojoyo Bangkalan. 